The Geneva Papers, 2005, 30, (144-170)

(C) 2005 The International Association for the Study of Insurance Economics 1018-5895/05 \$30.00

www.palgrave-journals.com/gpp

\title{
Terrorism Risk Coverage in the Post-9/11 Era: A Comparison of New Public-Private Partnerships in France, Germany and the U.S."
}

\author{
Erwann Michel-Kerjan ${ }^{\mathrm{a}, \mathrm{b}}$ and Burkhard Pedell ${ }^{\mathrm{c}}$ \\ ${ }^{\mathrm{a}}$ Center for Risk Management and Decision Processes and OPIM Department - The Wharton School, \\ University of Pennsylvania, Jon M. Huntsman Hall, Ste 500, 3730 Walnut Street, Philadelphia, PA 19104, \\ U.S.A. E-mail: erwannmk@Wharton.upenn.edu \\ ${ }^{\mathrm{b}}$ Ecole Polytechnique, Laboratoire d'Econométrie, Paris, France. \\ ${ }^{\mathrm{c}}$ Munich School of Management, Institute for Production Management and Management Accounting, \\ Ludwigstr. 28, 80539 Munich, Germany. E-mail: pedell@bwl.uni-muenchen.de
}

The paper discusses the development and operation of terrorism insurance programmes established in France, Germany and the U.S as reaction to 9/11. These three programmes are all based upon a public-private partnership with government backup. However, there are some fundamental differences regarding issues such as exclusions, price differentiation, risk mutualization, current level of terrorism insurance demand and the government exit strategy. In particular, significant differences of prices and degree of market penetration in the three countries have been observed and we discuss some factors that could contribute to this. Recent changes in the nature of international terrorism worldwide indicate that these issues will remain in our future. Hence, we think that government and industry would at the very least benefit from better understanding of how others operate abroad.

The Geneva Papers (2005) 30, 144-170. doi:10.1057/palgrave.gpp.2510009

Keywords: terrorism; extreme events; risk sharing; risk pricing; public-private partnerships; national security

\footnotetext{
* We thank Deborah Klauder, Howard Kunreuther, Fabrice Lebourgeois, Catherine Mikton, Andreas Richter and an anonymous referee for discussions and helpful comments on earlier versions of this paper. We appreciate insights from Bruno Gas (CEO of Extremus), Dirk Harbrücker (Extremus), Kerstin Paehler (Extremus), Jacques de Paris (Chairman of GAREAT) and François Vilnet (Vice-chairman of GAREAT). We also benefited from fruitful discussions on related issues with participants of the Wharton Risk Center's "Managing and Financing Extreme Events" Meeting, the Lawrence Livermore National Laboratory "Living with Risk" workshops at UC Berkeley and in Boston, the NBER Insurance Group workshop in Cambridge, MA, the Institute for Sustainable Development and International Relations (IDDRI) "Insurance and Mutualization" workshop in Paris and at the GMUHarvard "Private Efficiency, Public Vulnerability" workshop in Cambridge, MA, Harvard University's Kennedy School of Government, as well as with members of the OECD Task Force on Terrorism Insurance on which Michel-Kerjan serves.

Michel-Kerjan wishes to thank Lockheed Martin, Wharton-Columbia Radiant Trust, the Institut Veolia, the EDF-Polytechnique Chair on Sustainable Development and the Wharton Risk Management and Decision Processes Center for scientific and financial support of this project. Pedell gratefully acknowledges financial support of the Deutsche Forschungsgemeinschaft and the Fulbright Commission.
} 


\section{Introduction}

Although international terrorism is not a new risk, the way it is perceived has changed radically with the terrible events of September 11, 2001. These attacks killed more than 3,050 persons from 90 different countries, leading people to reanalyse the threat of terrorist attacks to which they may be exposed. The attacks also made clear how the nature of international terrorism has changed over the past two decades with religious terrorist groups seeking to inflict attacks that create a high number of injuries and fatalities. ${ }^{1}$

The September 11, 2001 attacks (9/11) against the United States (U.S.) raised numerous questions related to counter-terrorism, foreign policy, as well as national security in the U.S. and abroad. They also raised the fundamental question of who should pay for losses due to terrorism. Indeed, these attacks, which constitute the costliest event ever in the history of insurance, inflicted direct damage currently estimated at nearly $\$ 80$ billion, about $\$ 32.5$ billion of which was insured. ${ }^{2}$ Reinsurers (most of them European) have covered nearly two-thirds of the insured losses. ${ }^{3}$ Having their capital base severely hit, most of them decided to drastically reduce their exposure to terrorism risk, or even stopped covering such risk in the aftermath of $9 / 11 .^{4}$

The event also revealed highly correlated risks at two different levels. First, multiple lines were affected instantaneously on $9 / 11$ such that commercial property, business interruption, workers' compensation, life, health, disability, aircraft hull and general liability lines each suffered catastrophic losses. Secondly, there is now a wellrecognized possibility for several catastrophic attacks to occur simultaneously in different densely populated and industrialized locations. Hence, this event confronted the insurance and reinsurance industries with an entirely new loss dimension. Indirect effects on social and economic activities in the U.S. (especially in New York City) and abroad were even more important. ${ }^{5}$

Terrorism is now recognized as a national issue because it has a potentially debilitating impact on the social and economic activities of a country. This paper investigates how the public and private sectors have established partnerships for covering terrorism risk as a reaction to the 2001 terrorist attacks. We address this question by focusing on commercial insurance in three markets: France, Germany and the United States.

The analysis of these three countries is interesting not only because they all established a new terrorism insurance programme after 9/11, but also because they present three different approaches in dealing with this issue. In France, insurance coverage is mandatory and insurers have to provide that coverage; they are reinsured by a pool of co-reinsurance with unlimited government backup. In Germany, a property insurance corporation with limited government backup has been set up by insurance and reinsurance companies, but terrorism coverage is not mandatory. In the U.S., coverage is not mandatory either but insurers have to provide it should their policy holders want it. And although the Federal Government shares

\footnotetext{
1 Sandler and Enders (2004).

${ }^{2}$ Hartwig (2004).

${ }^{3}$ Dubois (2004).

${ }^{4}$ Liedtke and Courbage (2002).

${ }^{5}$ Lelain et al. (2002); de Mey (2003).
} 
part of the risk with insurers, there is no risk mutualization among insurers (no pool) in the U.S.

The paper is divided into three main sections. The next section describes and analyses the establishment and functioning of the three public-private partnerships: the French GAREAT established in December 2001, the German Extremus established in September 2002 and the U.S. Terrorism Risk Insurance Act of 2002 (TRIA), which was passed in November 2002. The subsequent section discusses further aspects such as the role of reinsurers, terrorism catastrophe bonds, rating agencies, and the importance of government participation in national terrorism risk insurance programmes. The penultimate section provides some evidence on the current level of demand for insurance coverage in these three markets. Finally, a conclusion summarizes the results and raises open questions for future research.

An Appendix provides a table of similarities and differences among these three programmes. Although this paper focuses on France, Germany and the United States, the Appendix also provides elements of programmes in place in Spain (Consorcio) and in the United Kingdom (Pool Re), as these two other European countries have suffered waves of terrorist attacks and created, far before 9/11, terrorism insurance programmes that are still in place.

Three years after the 9/11 attacks, and with the current threat of international terrorism, this paper could help multiple stakeholders (insurers, reinsurers and other firms as well as policymakers) to better understand how this question has been addressed abroad, how well foreign solutions are working in practice and whether some features would be beneficial to other countries.

\section{National insurance programmes for covering terrorism risk}

\section{GAREAT: the French programme}

Timeline. Negotiations between the French government and private insurers took place during the autumn of 2001 in a highly turbulent atmosphere. First, France had suffered several waves of deadly terrorist attacks during the 1980s and the 1990s. The explosion of the chemical factory AZF on September 21, 2001 - only 10 days after the attacks of 9/11 - in the densely populated French city of Toulouse killed 30 people and injured several thousands. This disaster constitutes one of the most important industrial catastrophes of the past 15 years in Europe. But at the time of the incident it was not clear whether the explosion was an accident or an attack and thus increased the perceived threat of terrorist attacks on French soil.

Secondly, from a legal perspective, the situation in France was especially acute because the law does not allow commercial property insurers to dissociate terrorism coverage from commercial property. Indeed, the law of September 9, 1986, obligates insurers to provide terrorism coverage up to the overall limits of a property policy. Hence, in the aftermath of $9 / 11$, French insurers who had decided to stop covering terrorism would have had also to stop covering commercial property at the 2002 renewals. As a result, many businesses would have been left not only without coverage against terrorism but also without commercial property damage and business interruption protection. 


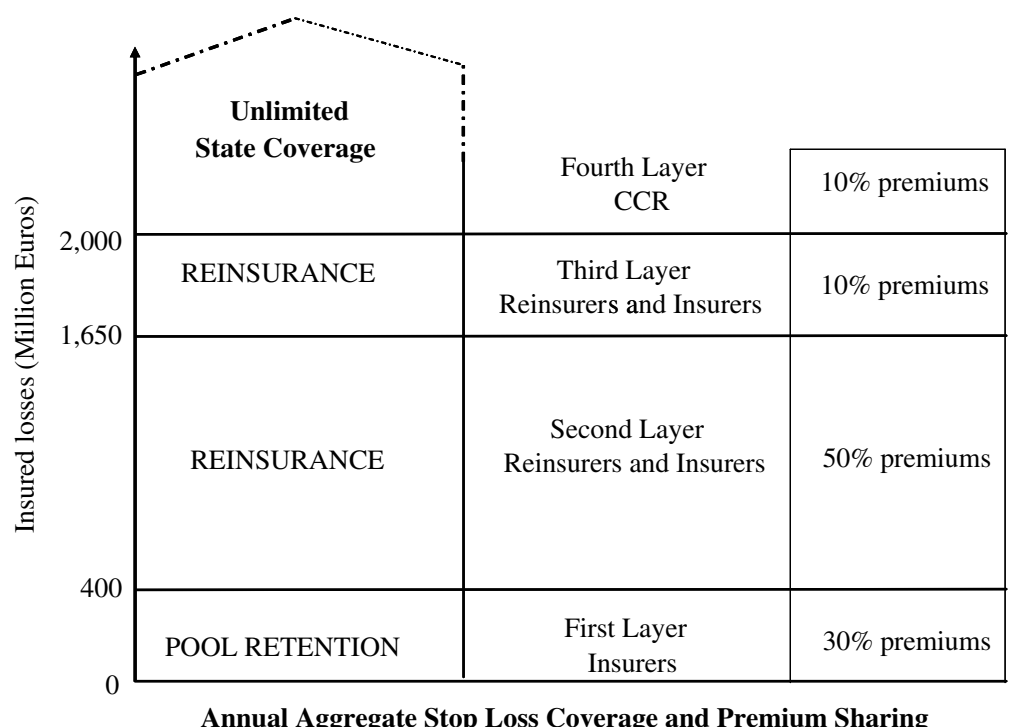

Figure 1. The French GAREAT.

Discussions took place in October 2001 between representatives of French insurers and the government. Eventually, the French government signed an agreement with FFSA and GEMA, ${ }^{6}$ the two major representative institutions of the French insurance market, on December 10, 2001. This agreement is based on a public-private partnership that created a specific national terrorism pool of co-reinsurance, the GAREAT, ${ }^{7}$ the first post-9/11 state-backed terrorism pool. As a result, commercial terrorism coverage in France has continued uninterrupted in spite of the September 11 events.

Structure of the public-private partnership. The GAREAT is a co-reinsurance pool organized under a four-tier structure of risk sharing and shareholders. It operates on an aggregate annual excess of loss basis (Figure 1).

As of 2004, the first layer presents an annual aggregate capacity of $€ 400$ million. ${ }^{8}$ It shares the risk through co-reinsurance among all members of the pool pro-rated to their share of ceded business (nearly 70 non-life FFSA and GEMA companies for which the membership is compulsory and nearly 35 other companies operating in the French market which chose to join). The second layer of coverage is written by reinsurers and some insurers that participate in the first line of the GAREAT. It has an annual aggregate capacity of $€ 1,250$ million. ${ }^{9}$ Swiss $\operatorname{Re}$ leads this placement in partnership with nearly 30 other firms among which are AIG, AXA, AGF, Hannover

${ }^{6}$ FFSA, Federation Française des Sociétes d'Assurance, is the association of the French insurers; GEMA, Groupement des Entreprises Mutuelles de l'Assurance, is the association of French mutuals.

${ }^{7}$ Gestion de l'Assurance et de la REassurance des risques attentats et Actes de Terrorisme (GAREAT) (Management of Insurance and Reinsurance against Terrorist Acts).

${ }^{8}$ Vs. $€ 250$ million in 2002 and $€ 400$ million 2003.

${ }^{9}$ Vs. $€ 750$ million excess of $€ 250$ million in 2002, respectively $€ 1,100$ million excess of $€ 400$ million in 2003. 
Re, Munich Re, Partner Re and Scor. These two layers provide a total capacity of $€ 1,650$ million. ${ }^{10}$

The third layer, led by Hannover Re, is placed on international reinsurance markets for an additional $€ 350$ million. Hence, in total the insurance and reinsurance industry covers insured losses of up to $€ 2$ billion. The fourth layer is an unlimited guarantee by the French government provided through the Caisse Centrale de Réassurance (CCR), a state-owned reinsurance company.

The premiums levied by insurers against policyholders are transferred to GAREAT and shared as follows: GAREAT keeps nearly 30 per cent, the second layer 50 per cent, the third layer 10 per cent, and the government receives nearly 10 per cent of the total annual premiums collected. ${ }^{11}$

Eligibility for coverage. Terrorism insurance is mandatory in France, so every single firm is covered by its insurer, which then can be reinsured by the pool GAREAT if the risk is eligible for coverage. To be eligible for this new coverage, the risks have to address three concurrent factors. First, the pool covers a large range of French commercial and industrial risks for property damage and business interruption including chemical, biological, radiological and nuclear (CBRN) attacks. ${ }^{12}$ Secondly, the risk has to be located in France. ${ }^{13}$ Finally, the pool covers only property for which the total insured coverage for direct property damage and business interruption (basic fire insurance policy) is higher than $€ 6$ million (medium/large risks only). Therefore, the French solution does not provide a complete mutualization of risks among insurers. Rather, it offers a combination of major risks reinsured by the pool and a normal reinsurance capacity provided by the market for simple commercial risks (e.g. car insurance). Moreover, the same deductible is applied for terrorism as for other property coverage.

Risk pricing. Reinsurance rates by GAREAT apply as a percentage of the property premiums and depend only on the total insured value, for which four segments are defined, as depicted in Figure 2.

For total sums insured higher than $€ 6$ million and lower than $€ 20$ million, the insurer pays a terrorism premium equal to 6 per cent of the commercial property and business insurance premium paid by the insured; for a sum insured higher than $€ 20$ million but lower than $€ 50$ million, the applied percentage is 12 per cent. When the sum insured is higher than $€ 50$ million, the insurer pays a premium equal to 18 per cent of the basic insurance premium (see Figure 2). ${ }^{14}$ Finally, for "special risks" (nuclear plants, captives or property over $€ 750$ million) the rate is quoted

${ }^{10}$ The maximum capacity for each reinsurer is based on capital and ratings, from $€ 300$ million for $S \& P$ AAA-rated reinsurers to $€ 10$ million for BBB-ones.

${ }^{11}$ A new decree was passed in 2002 authorizing non-taxable equalization reserves for insurers on terrorism premiums in the cumulated limit of 500 per cent of the annual terrorism premium.

12 GAREAT does not cover liability risks and personal lines.

${ }^{13}$ Including overseas territories and departments as well as Mayetta; assaults to foreign affiliates of French firms are thus not covered.

${ }^{14}$ The French decree dated December 31, 2002 allows firms with sum insured higher than €20 million to limit their coverage for acts of terrorism to 20 per cent of the property damage guarantee for which a reduction could be granted. 


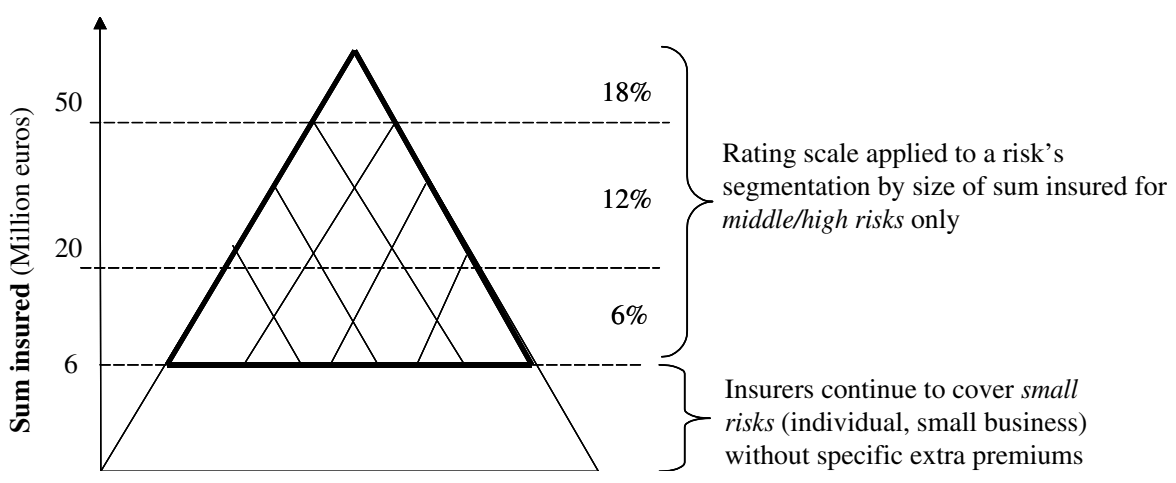

Figure 2. Reinsurance premium rates by GAREAT.

individually. ${ }^{15}$ It must be stressed that these rates are the same no matter what the location or the nature of the risk. We discuss the issue of flat rates vs. risk-rate premiums in the next section.

According to data provided by GAREAT, the estimations of the total premiums collected by the pool were $€ 260$ million for 2004 and the average annual "terrorism coverage price" was 0.10 per thousand of the total insured value.

Renewal and government exit strategy. The pool was first set up for a single year with the option of being renewed, as was done for 2003. After 2 years of operation, the agreement has been extended for 3 additional years and will end December 31, 2006. This renewal came with a capacity of private partners that has doubled to $€ 2$ billion between 2002 and 2004. While retention by the first layer (pool retention) has not been modified since the creation of GAREAT, it is supposed to start increasing in 2005 to a level still under discussion. The increase of the total capacity provided by the insurance and reinsurance industries should continue in the coming years in order to limit the need of governmental intervention for extreme events. Moreover, after three years without major attacks, the price of coverage by GAREAT for large risks, currently rated at 18 per cent of the basic premium, could decrease in the coming years. ${ }^{16}$

\section{EXTREMUS AG: the German programme}

Timeline. As in many other countries, insurance against terrorism risk in Germany was included in most commercial lines without an extra premium until the events of 9/11. After these events, many insurance companies excluded terrorism risk from commercial insurance lines for sums insured higher than $€ 25$ million; others offered

${ }^{15}$ As of 2004, nearly 90,000 policies have been contracted with GAREAT on an annual basis. Around 70 per cent of the policies are contracted for sums insured of less than $€ 20$ million but they represent only around 20 per cent of the total premiums. Policies with sum insured above the threshold of $€ 50$ million represent only 10 per cent but count for nearly 60 per cent of the total premiums (Partner Re, 2004; GAREAT, 2004).

${ }^{16}$ We are grateful to members of GAREAT for providing us with this information. 


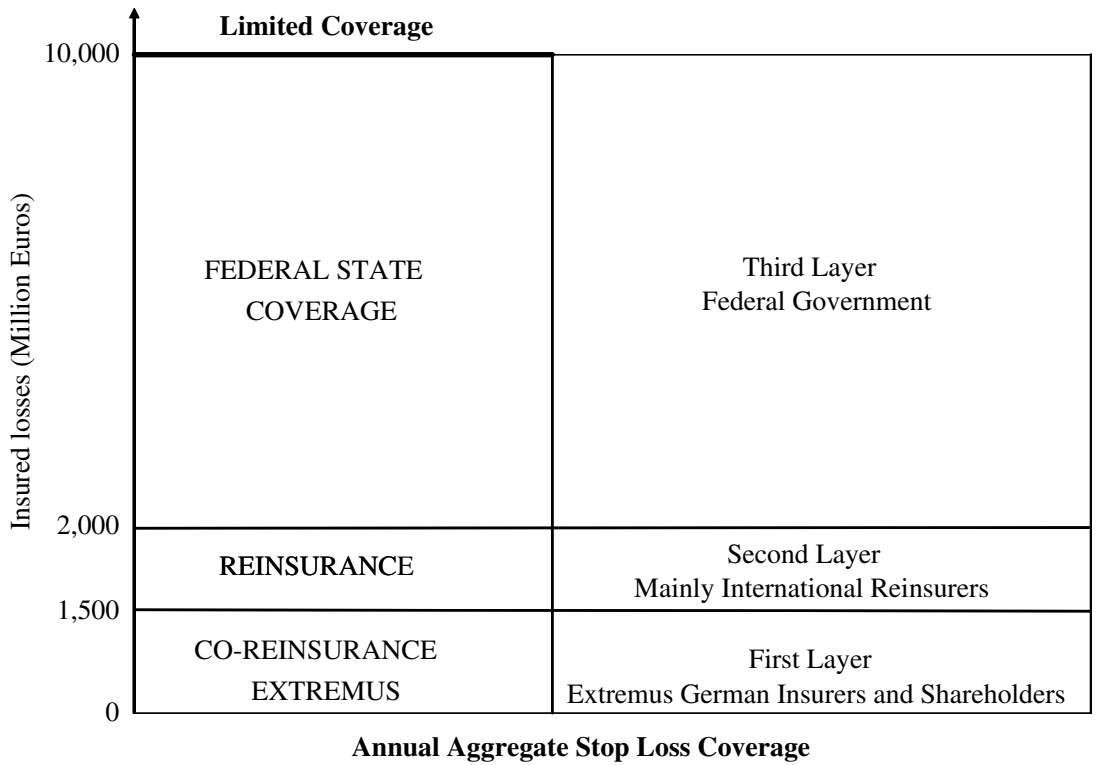

Figure 3. The German Extremus AG.

coverage with fairly restrictive upper loss limits against an extra premium. As reinsurance capacity for that very risk was practically no longer available, insurance companies were not willing to cover terrorism risk by themselves. ${ }^{17}$

The German solution for terrorism insurance resulted from 6 months of negotiations between the German government and the German Insurance Association GDV (Gesamtverband der Deutschen Versicherungswirtschaft). Chancellor Gerhard Schröder and the Federal Minister of Finance Hans Eichel announced at a press conference on April 23, 2002 that the Federal Government would set up a partnership with the private insurance industry by providing a limited state coverage. The programme was based on the September 3, 2002 creation of a new property insurance corporation, Extremus AG. After approval by the Federal Commission for the Supervision of Financial Services, Extremus went into business on November 1, 2002.

Structure of the partnership. Extremus directly covers terrorism risk. It is 100 per cent reinsured by its shareholders, which are private insurance and reinsurance companies, ${ }^{18}$ by national and international insurance and reinsurance companies as well as by the federal government. As depicted in Figure 3, the annual coverage capacity provided in three layers from March 1, 2004 on has been limited to $€ 10$ billion. The liability of Extremus and its shareholders is limited due to the legal status of the corporation. Hence, in the case that cumulative losses inflicted by terrorist

\footnotetext{
${ }^{17}$ Gas and Thomann (2003).

${ }^{18}$ The 16 shareholders are AIG, Allianz, AMB, Deutsche Rück, DEVK, Gerling Allgmeine, Gothaer, HDI, HUK Coburg, LVM, Munich Re, NOVA Allgemeine, R+V, Swiss Re, VHV and Zürich.
} 
attacks in 1 year exceed $€ 10$ billion, Extremus is likely to be obliged to announce insolvency. As a result, the losses exceeding $€ 10$ billion would not be compensated at the time of insolvency and would fall back completely on the insureds. Such a situation would presumably bring the discussion of alternative solutions such as cost sharing back to the political agenda. ${ }^{19}$

The shareholders of Extremus provide the major part of the first layer of $€ 1.5$ billion. The second layer of $€ 0.5$ billion is provided mainly by international reinsurers lead by Berkshire Hathaway. Above this level, the federal government takes the role of a reinsurer of last resort; that is, if claims in a given year pass $€ 2$ billion. ${ }^{20}$ In contrast to the French scheme, government liability is limited in the German programme. ${ }^{21}$

The premium income is collected by Extremus and distributed among the participating partners, including the government. The first year the scheme was established, the government received 9 per cent of the total premiums for providing reinsurance to Extremus. This premium is not exempt from insurance tax.

Eligibility for coverage. Insurance against terrorism is not mandatory in Germany. Insurance by Extremus covers buildings, contents of buildings such as machinery, as well as business interruption against terrorist acts. Acts of terrorism are defined as acts by persons or groups of persons committed for political, religious, ethnic or ideological purposes intended to create fear in the population or any section of the population and thus to influence a government or public body. ${ }^{22}$ To be eligible for coverage, the act of terrorism has to be committed in Germany, and the damage has to have occurred on German soil.

Extremus covers terrorism risk only for a total insured value over $€ 25$ million. War and civil war, insurrection, looting, nuclear risks as well as biological and chemical contamination by terrorists are excluded. Damages caused by computer viruses are explicitly excluded also.

Risk pricing. Terrorism risk coverage can only be signed in connection with existing property and/or business interruption insurance. It applies to the basic total insured value for property and business interruption. A firm that wants to purchase terrorism coverage needs also to pre-determine a specific maximum annual compensation for terrorism coverage. This annual compensation is capped at a maximum of $€ 1.5$ billion for every firm. This means that a firm with a total sum insured higher than $€ 1.5$ billion

${ }^{19}$ Gas and Thomann (2003).

${ }^{20}$ It is worth noting that the low demand for terrorism insurance coverage in Germany during 2003 (see The demand for terrorism coverage section) contributed to the decision to reduce this second layer from $€ 1.5$ billion in 2003 to $€ 0.5$ billion as of March 1, 2004 in order to decrease reinsurance premiums paid by Extremus and to enable Extremus to operate cost-covering. At the same time, the state coverage decreased from $€ 10$ billion to $€ 8$ billion (Frankfurter Allgemeine Zeitung, 2004).

${ }^{21}$ Indeed, according to German federal budget law, liabilities have to be accounted for in the federal budget that is subject to rules that limit the raising of new debt; as a consequence, the government is prohibited from taking unlimited liabilities.

22 "Terrorakte sind jegliche Handlungen von Personen oder Personengruppen zur Erreichung politischer, religiöser, ethnischer oder ideologischer Ziele, die geeignet sind, Angst oder Schrecken in der Bevölkerung zu verbreiten und dadurch auf eine Regierung oder staatliche Einrichtung Einfluss zu nehmen."; general conditions for the insurance of terrorism risk by Extremus AG, p. 1 (www.extremus.de). 
The Geneva Papers on Risk and Insurance-Issues and Practice

152

Table 1 Insurance Premiums by Extremus*

\begin{tabular}{|c|c|c|c|c|}
\hline \multirow{2}{*}{$\begin{array}{l}\text { Total insured } \\
\text { value (a) }\end{array}$} & \multirow{2}{*}{$\begin{array}{l}\text { Maximum annual } \\
\text { compensation for } \\
\text { terrorism (b) }\end{array}$} & \multicolumn{3}{|c|}{ Annual premium for terrorism coverage } \\
\hline & & In Euro & In \%o of $(a)$ & In \%o of $(b)$ \\
\hline 25 million & 25 million & 6,250 & 0.25 & 0.25 \\
\hline 50 million & 25 million & 8,438 & 0.17 & 0.34 \\
\hline 75 million & 25 million & 10,625 & 0.14 & 0.43 \\
\hline 50 million & 10 million & 6,250 & 0.13 & 0.63 \\
\hline 50 million & 30 million & 9,250 & 0.19 & 0.31 \\
\hline 50 million & 40 million & 10,875 & 0.22 & 0.27 \\
\hline 50 million & 50 million & 12,500 & 0.25 & 0.25 \\
\hline 200 million & 50 million & 63,806 & 0.32 & 1.28 \\
\hline 200 million & 100 million & 84,038 & 0.42 & 0.84 \\
\hline 200 million & 200 million & 120,000 & 0.60 & 0.60 \\
\hline
\end{tabular}

*Data based on Extremus Versicherungs-AG (2003).

can get only partial coverage for terrorism risk. For instance, a firm with a sum insured of $€ 25$ billion cannot get coverage exceeding $€ 1.5$ billion, that is, only 6 per cent of its total insured value is covered for terrorism.

Hence, the premium charged by Extremus against the insured depends on two parameters: (1) the total sum insured of the firm and (2) its choice of a maximum annual compensation capped at $€ 1.5$ billion. By choosing a lower maximum annual compensation for losses due to terrorism, a firm can decrease its premium. Although internally Extremus has developed a complete scale of premiums, only a few examples of these premiums - and those exclusively for relatively low sums insured ${ }^{23}-$ are publicly available, as depicted in Table 1.

Thus, as in France, premiums are not differentiated with respect to industry or location of risk. Moreover, there are no premium discounts for mitigation measures taken by the insured. As of August 2004, according to data provided by Extremus, the total annual premium income received by the company was $€ 77$ million.

Renewal and government exit strategy. The 3-year agreement with the federal government is only through 2005. It is critical that reinsurance companies can build up reserves from premium surplus so as to facilitate the announced phasing out of the federal government's involvement. To this end, financial reporting standards for insurance companies were changed in May 2003, consequently

${ }^{23}$ This limits the analysis of the current operation of Extremus because the distribution of premium income is heavily biased towards the largest insurance contracts. The 12 largest contracts with maximum annual compensation between $€ 500$ million and $€ 1.5$ billion account for more than 50 per cent of the total net premium income, whereas contracts with a maximum annual compensation below $€ 100$ million make up for more than 85 per cent of the number of contracts but yield only 17 per cent of the total net premium income. 
exempting the building of reserves for terrorism risk coverage from corporate income taxes. ${ }^{24}$

Even if the layers covered by the insurance and reinsurance industries increase over time as planned, the shareholders of Extremus support the view that the federal government should extend its current participation beyond 2005. However, the Federal Ministry of Finance has indicated that its participation may not continue after 2005 unless demand for coverage increases (see The demand for terrorism coverage section). ${ }^{25}$ At the present time, it is unclear what will happen in 2006.

\section{The U.S. Terrorism Risk Insurance Act of 2002}

Timeline. As declared by insurers in European countries in the aftermath of the September 11 attacks, many U.S. insurers warned that another event of comparable magnitude could do irreparable damage to the industry. Further, they argued that the uncertainties surrounding terrorism risk were so significant that it was, in fact, an uninsurable risk if covered by the private market alone. When Congress failed to pass federal terrorism insurance legislation before adjourning in December 2001, members of the National Association of Insurance Commissioners were encouraged to approve terrorism exclusions from new policies. By early 2002, no fewer than 45 states permitted insurance companies to exclude terrorism from their policies, with the exception of workers' compensation insurance policies that cover occupational injuries without limit regardless of the peril that caused the injury. ${ }^{26}$ This led to a very thin market for terrorism-related losses and when available, terrorism coverage carried strong limitations at a very high price.

For example, prior to 9/11, Chicago's O’Hare airport had $\$ 750$ million of terrorism insurance coverage at an annual premium of $\$ 125,000$. After the terrorist attacks insurers only offered the airport $\$ 150$ million of coverage at an annual premium of $\$ 6.9$ million. The airport purchased this coverage and could not obtain any more. ${ }^{27}$ Take the case of Golden Gate Park - not only was it unable to obtain any terrorism risk coverage, but coverage for non-terrorism risk was reduced from $\$ 125$ million to only $\$ 25$ million, while the premium increased from $\$ 500,000$ in 2001 to $\$ 1.1$ million in $2002 .^{28}$

On the first year anniversary of the attacks, the U.S. remained largely uncovered. ${ }^{29}$ Had the country suffered attacks at this time, they would have inflicted severe

\footnotetext{
${ }^{24}$ This possibility is capped at a certain level defined by law, namely at the policy limit for reinsured risks and at 15-fold the annual premium income earned for insured risks (Erste Verordnung zur Änderung der Verordnung über die Rechnungslegung von Versicherungsunternehmen, May 27, 2003; Bundesgesetzblatt, 2003, Part I, No. 21).

25 Extremus (2004).

${ }^{26}$ For that very reason, worker's compensation, which is the largest commercial line in the U.S. with $\$ 42$ billion in 2002 direct written premiums (including state funds), is certainly the most vulnerable line. A recent study by Towers Perrin, (2004) estimates that an anthrax attack against NYC could inflict $\$ 90$ billion of insured losses for workers compensation as a worst-case scenario. As an element for comparison, this line suffered a \$2 billion loss in the 9/11 attacks. MacDonald (2004) provides a very comprehensive discussion on this issue.

${ }^{27}$ Jaffee and Russell (2003).

28 Smetters (2004).

${ }^{29}$ Hale (2002).
} 


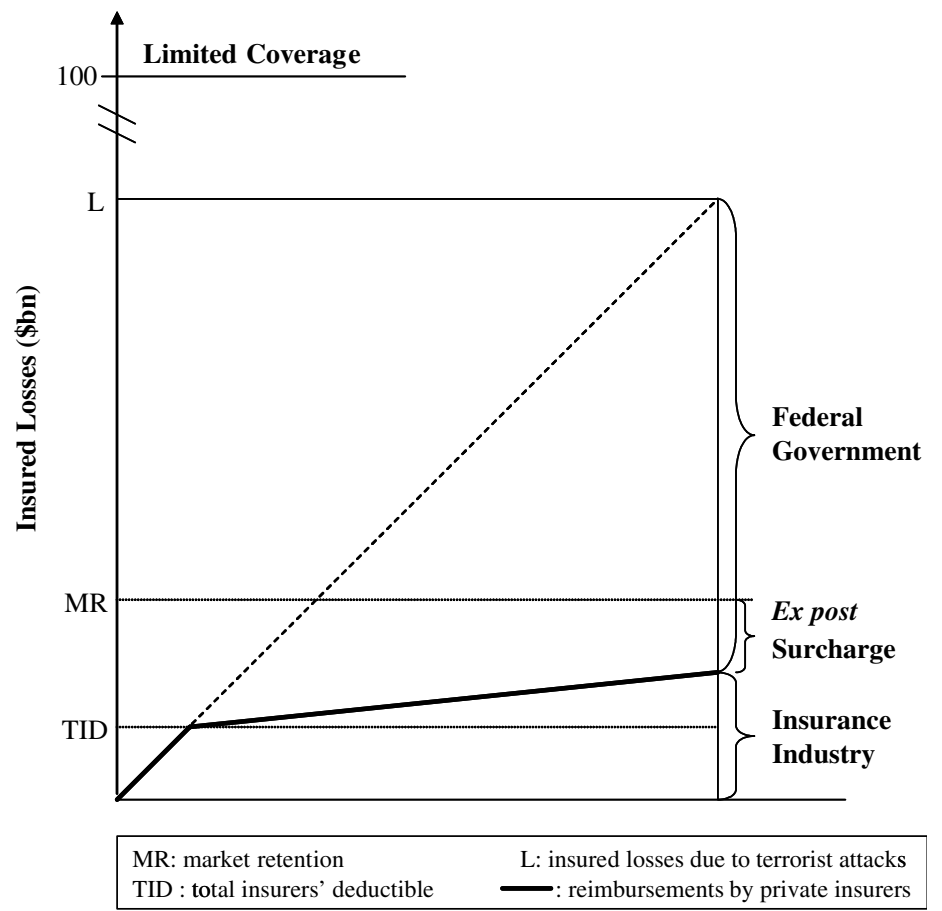

Figure 4. The U.S. TRIA.

financial consequences on affected businesses deprived of coverage. After the 2002 midterm elections, the Terrorism Risk Insurance Act of 2002 (TRIA) was eventually passed by Congress on November 26, 2002, and signed into law by President Bush the next month. It provides for up to $\$ 100$ billion of terrorism risk coverage.

Structure of the U.S. partnership. Under TRIA's 3-year term ending December 31, 2005 , there is a specific risk-sharing arrangement between the federal government and insurers that operates as follows. First, the federal government is responsible for paying 90 per cent of each insurer's primary property-casualty losses during a given year above the applicable insurer deductible up to a maximum of $\$ 100$ billion (Figure 4). The insurer's deductible is determined as a percentage of the direct commercial property and casualty earned premiums of each insurer the preceding year. The percentage varies over the 3-year operation of the programme: 7 per cent in 2003, 10 per cent in 2004 and 15 per cent in $2005 .^{30}$

If the insurance industry suffers terrorism losses that require the government to cover part of the claims, then these outlays shall be partially recouped ex post through a mandatory policy surcharge against the insurers. In turn, insurers shall levy that

${ }^{30}$ A recent study estimates that AIG's 2004 deductible would have been $\$ 2.7$ billion; others like Travelers, ACE, Chubb or Berkshire would have had lower 2004 deductibles: \$928 million, \$743 million, \$600 million and \$200 million, respectively (Morgan Stanley, 2004). 
surcharge against all property and casualty insurance policyholders whether or not the insured has purchased terrorism coverage, with a maximum of 3 per cent of the premium charged under the policy that year. This recoupment applies only for federal reimbursements comprising the total payments by the insurance industry (threshold) and the insurance marketplace retention amount (MR) (ceiling) as depicted in Figure 4. This market retention evolves as follows: $\$ 10$ billion in 2003, $\$ 12.5$ billion in 2004 and $\$ 15$ billion in 2005. For insured losses above the marketplace retention, federal reimbursement cannot be recouped afterward.

It is worth noting that the federal government does not receive any premium for providing this reinsurance coverage (e.g. in 2005, $\$ 85$ billion on top of $\$ 15$ billion that would be paid eventually by insurers and policyholders). This means that insurers receive federal reinsurance free of charge. Hence, the final price of insurance coverage under TRIA remains much lower than it would otherwise, should the price of such reinsurance be included. Finally, more than 150 insurers and reinsurers worldwide shared insured losses on September 11, 2001. Under TRIA, without any risk mutualization at the level of the insurance industry, loss due to a future attack would be exclusively covered by insurers whose policyholders are hit.

Eligibility for coverage. Under TRIA, insurers are obliged to offer terrorism coverage to all their insureds (a legal "make available" requirement) and, as in France, the coverage limits and deductibles must be the same as for any loss from other major perils on their commercial policy. Clients are able to turn this coverage down (i.e. a mandatory offer but no mandatory coverage). Insured losses are covered under TRIA only if the event is certified by the Treasury Secretary as an "act of terrorism" and only for total losses higher than \$5 million. According to TRIA, an "act of terrorism" has to be "committed by an individual or individuals acting on behalf of any foreign person or foreign interest, as part of an effort to coerce the civilian population of the U.S. or to influence the policy or to affect the conduct of the U.S. Government by coercion". Therefore, an event like the Oklahoma City bombing of 1995, which killed 168 people and had been the most damaging attack on domestic soil to date, would not have been covered under TRIA because it was considered as "domestic terrorism". Moreover, losses resulting from CBRN terrorist attacks are covered by TRIA only if they are in the original property and business interruption insurance policy, which is the case of very few policies. ${ }^{31}$ In addition, TRIA does not cover life insurance.

Risk pricing. TRIA does not define any national rule to be applied for insurance rates as was done for GAREAT or Extremus. Hence, there is no simple answer to the question of how two different insurance companies have priced terrorism coverage for their clients.

At the end of 2002, the U.S. Insurance Services Office (ISO) used the estimates provided by AIR Worldwide (one of its subsidiaries) to file advisory loss $\operatorname{costs}^{32}$ with

${ }^{31}$ Marsh Inc. (April 2004).

${ }^{32}$ A loss cost is defined by ISO as that portion of a rate that does not include provision for expenses (other than loss adjustment expenses) or profit. It may be used by ISO companies as a starting point to set insurance rates, after reflection of company-specific expenses and profit. Once an ISO advisory loss cost has been approved by a state, an ISO participating insurance company can usually adopt it without having to undertake its own often lengthy and expensive rate filing process (Kunreuther, Michel-Kerjan and Porter, in press). 
156

the insurance commissioner for each state. ISO defined three tiers for the country, placing certain areas within Chicago, New York City, San Francisco and Washington, DC, in the highest tier, with assigned loss costs of approximately $\$ 0.10$ per $\$ 100$ of property value. A second tier consisted of Boston, Houston, Los Angeles, Philadelphia and Seattle as well as other portions of the highest rated cities; the rest of the country fell into the third tier. In pre-filing discussions with regulators, ISO's advisory loss costs were challenged by some regulators who felt that such premiums would lead businesses to relocate to other areas. ${ }^{33}$ Negotiations ensued and compromises were made. ISO filed loss costs for first-tier cities based on zip code, which differentiated between the higher risk of downtown city centres and the lower risk of properties on the outskirts. But nowhere did the filed loss costs exceed $\$ 0.03$ per $\$ 100$ of property value in the first tier; and the second and third tiers settled at $\$ 0.018$ and $\$ 0.001$, respectively, per $\$ 100$ of property value. Thus, while the new levels no longer adequately reflected the risk in the eyes of the modellers, they became more palatable to other stakeholders. The Departments of Insurance in all 50 states eventually approved these ISO advisory loss costs that covered the years 2003, 2004 and 2005. ${ }^{34}$

A few months later, rates started decreasing. While there is not a lot of data currently available on the U.S. market for terrorism insurance, a few studies provide interesting findings. According to a national survey undertaken by Marsh Inc., of over 2,400 client firms during the second, third and fourth quarters of 2003, the average median terrorism premium as a percentage of their overall property premium was 4.4 per cent, compared with 10.8 per cent for the first quarter of $2003 .{ }^{35}$ That percentage obviously depends on which sector ${ }^{36}$ and location ${ }^{37}$ is considered.

According to this Marsh survey, the median rate for terrorism insurance applied to the total insured value over that three-quarter period of 2003 was 0.056 per thousand. ${ }^{38}$ That rate increased to 0.08 per thousand and 0.076 per thousand in the first and second quarters of 2004, respectively; virtually the same pricing as a year ago. This recent increase may actually not reflect an increase of the terrorism coverage price itself, but rather a pricing of commercial property insurance that has continued to soften. ${ }^{39}$

While these rates have decreased over the past 2 years, making terrorism coverage more affordable, it is not clear how they would evolve should another attack occur on

\footnotetext{
${ }^{33}$ Hsu (2003).

${ }^{34}$ Kunreuther, Michel-Kerjan and Porter (in press).

${ }^{35}$ Marsh Inc. (April 2004).

${ }^{36}$ According to the Marsh survey, it equalled 8 per cent for energy but only 2.3 per cent for the construction sector at a national level, as an average of the data obtained for the three last quarters of 2003 (Marsh, Inc. April 2004).

${ }^{37}$ During the autumn of 2003, the New York-based insurance brokerage firm Kaye Insurance Associates surveyed 100 of its clients at middle market real estate, retail, and manufacturing in the New York area on a series of insurance-related issues, including terrorism insurance. And while the prices have fallen in 2003, Manhattan properties are still paying a 20 per cent surcharge, according to the Kaye survey (Kaye, October 2003).

${ }^{38}$ That level has to be contrasted depending on what segment sector is analysed. For example, for the energy sector and real estate, the average medium rate was 0.13 per thousand, and 0.1 per thousand respectively, whereas it drops to around 0.04 per thousand for retail or health care (Marsh, April 2004).

${ }^{39}$ Marsh Inc. (August 2004).
} 
U.S. soil. It is also important to keep in mind that those numbers are based only on a limited sample of firms surveyed.

Taken together, and although there is no precise data on the total annual terrorism insurance premiums levied by insurers for TRIA covered lines including workers' compensation in 2004, recent estimations suggest those premiums are roughly $\$ 3.6$ billion. $^{40}$

Renewal and government exit strategy. The important question for the U.S. insurance industry as this paper goes to press is to know what will happen after December 31, 2005. One possibility is that TRIA will be renewed with some evolution in the thresholds of risk sharing between the insurance industry and the federal government. Actually, three bills were introduced in the summer of 2004 to extend the TRIA programme for an additional 2 to 3 years through to December 31, 2007: the House Democrats' bill (H.R. 4772), House Republican bill (H.R. 4634) and the bipartisan Senate bill (S. 2764). However, if this U.S. programme ends on December 31,2005 , alternative solutions will need to emerge and be implemented. This issue is discussed in a companion paper. ${ }^{41}$

\section{Discussion}

Similarities and differences among these three programmes - GAREAT, Extremus and TRIA - are summarized in the Appendix. The analysis of these public-private partnerships established after $9 / 11$ to cover commercial lines against terrorism risk obviously raises other questions as to who should partner with insurers in these programmes.

\section{The role of reinsurers}

As noted above, reinsurers paid nearly two-thirds of the insured losses caused by the terrorist attacks on September 11, 2001. Immediately after the event, most reinsurers strictly limited the coverage provided to insurers or left the market entirely.

As of today, the federal reinsurance provided to insurers is free of charge in the U.S. While the overall effect on the crowding-out of private solutions is not clear a priori, there is no way reinsurers can compete with a zero-cost federal terrorism reinsurance programme. To date, their role there is then limited to covering the deductible portion of the insurer's potential liability from a terrorist attack. As illustrated by GAREAT and Extremus, several reinsurers reentered the market by providing limited coverage as partners within national programmes where risks are pooled and mutualized among several partnering reinsurers. They may accept a similar role as in Europe should such a type of arrangement emerge in the U.S. when TRIA ends. ${ }^{42}$

\section{The issuance of terrorism cat bonds}

In the aftermath of major natural disasters in the early 1990s, including Hurricane Andrew which devastated the coast of Florida in August 1992 and inflicted \$20.5.

\footnotetext{
${ }^{40}$ Hubbard and Deal (2004).

${ }^{41}$ Kunreuther and Michel-Kerjan (in press).

${ }^{42}$ Ibid.
} 
billion of insured losses (2003 indexed price), property catastrophe reinsurance was in short supply. As a result, the price of reinsurance more than doubled in the U.S. compared with the late 1980s. To find capital from other sources insurers collaborated with the investment banking community and modelling firms to develop new classes of financial instruments such as options and catastrophe bonds. These alternative risk transfers were created to cover losses by transferring part of the risk to the capital markets, and providing investors with an appealing new class of assets. ${ }^{43}$ Although the market for risk-linked securities is still in its infancy, the total amount of risk-linked securities has amounted to over $\$ 9.5$ billion since its inception. ${ }^{44}$ However, this market is still considerably below the expectations of insurers, reinsurers and investment bankers, accounting for less than 3 per cent of worldwide catastrophe reinsurance coverage in $2002 .^{45}$

A market for catastrophe bonds to cover loss from terrorist attack has not emerged since $9 / 11$, and it is not clear how this will evolve in the future as the characteristics of terrorism risk make its securitization much more challenging than for natural disasters. ${ }^{46}$ To date, only two terrorism-related cat bonds have been issued. Neither of these, however, is actually a pure terrorism cat bond issued for a specific type of attack; both are multi-event cat bonds associated with the risk of terrorist attack and the risk of natural disasters or pandemic. ${ }^{47}$

\section{The role of rating agencies}

As another stakeholder, rating agencies could play a role by indicating whether a specific type of arrangement between insurers, reinsurers and the government would be more valuable to them. This would lead to higher ratings for the insurers and reinsurers that participate. However, it seems that the current volume of terrorism insurance by the public-private partnerships in the three countries is not yet high enough to significantly affect the rating of participating insurance and reinsurance companies.

${ }^{43}$ See for instance Godard, Henry, Lagadec and Michel-Kerjan (2002); Lane (2002); Nell and Richter (2004); Richter (2004).

44 Swiss Re (2004).

${ }^{45}$ U.S. General Accounting Office (2003).

${ }^{46}$ Michel-Kerjan (2003a); Kunreuther et al. (2003).

${ }^{47}$ The first bond was issued in August 2003 when the world governing organization of association football (soccer), the FIFA, which will organize the 2006 World Cup in Germany, developed a \$262 million bond to protect its investment. The bond is actually not a terrorism bond per se, but a multi-event bond. Under very specific conditions, the catastrophe bond covers against both natural and terrorist events that would result in the cancellation of the World Cup game without the possibility of it being re-scheduled to 2007 (U.S. General Accounting Office, 2003). The second terrorism-related bond is a securitization of catastrophe mortality risk that was undertaken in 2003 by Swiss Re, the world's largest life reinsurer. Mortality is measured with respect to a mortality risk index, weighted according to Swiss Re's exposure in several countries. The trigger threshold for the mortality index is 30 per cent higher than expected through the end of 2006, based on 2002 mortality rates in these countries. According to Woo (2004), the trigger threshold, which may represent 750,000 deaths, might be pulled before the end of 2006 only if pessimistic lethality estimates are made for both a pandemic and a terrorist attack using weapons of mass destruction, killing several hundreds of thousands of people. 
Moreover, the recent development of terrorism risk models could facilitate the rating agencies playing a role in encouraging the issuance of more terrorism catastrophe bonds. Nevertheless, since the first such models were released two years ago, most investors and rating agencies still consider terrorism risk models to be too new and untested to be used in conjunction with a catastrophe bond covering risks. Although these new models provided useful information on the potential severity of an attack, these are not very reliable in predicting the frequency of such attacks. ${ }^{48}$

\section{The role of government}

Although it would require a discussion that goes beyond the scope of this paper, there is bourgeoning literature debating whether the government or the private sector is better suited to provide adequate financial protection to potential victims of terrorism; or, more specifically, on the role of the government as reinsurer of extreme terrorism risk. ${ }^{49}$

The question of whether there should even be government intervention in the terrorism insurance market is discussed by others who contend that such intervention limits the development of private solutions that would likely emerge otherwise. ${ }^{50}$ Still others argue that the difficulties the private market of insurance faces in providing terrorism insurance alone result mainly from constraints imposed by the government that make it too costly to hold surplus capital and freely adjust prices (e.g. accounting, tax, regulation). ${ }^{51}$

Building on other recent contributions, ${ }^{52}$ we contend that terrorism presents a set of characteristics that differ from other catastrophic risks like natural disasters in the following ways: limited relevant data, difficulty to quantify probability, dynamic uncertainty depending over time on the terrorists' will to attack and their chosen modes, among others. We also contend that international terrorism is a foreign policy issue and a matter of national security. ${ }^{53}$ This raises the question of government responsibility in dealing with terrorism and call for government participation in any national programme covering economic losses due to terrorist attacks, as part of its national security policy. ${ }^{54}$

Government protection against catastrophic losses associated with mega-terrorism (relative to each country's insurance market) is particularly important as such events pose severe problems of liquidity and possible insolvency to insurers and reinsurers. On the other hand, the government has the capacity to provide this type of coverage, as it can diversify the risks over the entire population and spread past losses to future generations of taxpayers. Because of the incompleteness of inter-generational private markets, this is a form of cross-time diversification that the private market cannot achieve. ${ }^{55}$

\footnotetext{
${ }^{48}$ Kunreuther et al. (in press).

49 Brown et al. (2002); Cummins and Doherty (2002); U.S. General Accounting Office (2001, 2002); Russell (2003); Brown et al. (2004).

${ }^{50}$ Gron and Sykes (2002); Jaffee and Russell (2003).

51 Smetters (2004).

${ }^{52}$ Michel-Kerjan (2003b); Kunreuther and Michel-Kerjan (in press); Kunreuther and Michel-Kerjan (forthcoming).

${ }^{53}$ Pillar (2001); National Commission (2004).

${ }^{54}$ White House (2002).

55 Smetters (2004).
} 
Government participation is actually unlimited in France. As discussed, although limited in the U.S., federal coverage represents no less than 90 per cent of insured losses above a specific threshold; should the country suffer extreme terrorism losses, the U.S. federal government (hence the taxpayers) would be the prime contributor. ${ }^{56}$

\section{Linking insurance with risk mitigation}

When adequately designed, insurance coverage can also play an important role in encouraging firms to invest in mitigation measures, hence limiting the consequences of an attack. However, an insurer on its own may not be in a position to offer this type of economic incentive for terrorism coverage due to interdependencies. Indeed, the risk of an attack that one organization is exposed to depends not only on its choice of security investments, but also on the actions of other agents, a type of interdependent security, as recently introduced by Kunreuther and Heal. ${ }^{57}$ For example, the collapse of the World Trade Center on September 11, 2001 could be attributed in part to the failure of security at Logan airport in Boston where terrorists were able to board planes that flew into the WTC.

At this time, none of these three programmes has yet developed a systematic incentive policy such as premium or deductible reduction for encouraging the insureds to invest in security measures (only rare anecdotes have been reported). Whether this absence of a systematic link between terrorism insurance and mitigation is due mainly to a lack of interest on the part of insurers or to the difficulty and cost of evaluating the real efficiency of such security measures in the presence of interdependencies is not clear yet.

\section{Demand for terrorism coverage: evidence from the three markets}

This section discusses the level of demand for terrorism insurance in France, Germany and the U.S. As the U.S. TRIA and the German Extremus have been operating for less than 2 years, it is too early to get extensive data on the market penetration of terrorism insurance. Only a few surveys conducted in the U.S. have been published to date, yet they present an interesting picture of the demand for terrorism coverage 3 years after the $9 / 11$ attacks.

\section{The French market}

As commercial insurance for terrorism is mandatory in France, 100 per cent of firms are covered. Hence this avoids low levels of demand that could result from adverse selection, ${ }^{58}$ as observed in Germany (see below).

\footnotetext{
${ }^{56}$ The German and U.S. caps of governmental participation are high relative to each market and potential worst-case scenario; so this cap provides implicitly an almost-unlimited governmental coverage.

${ }^{57}$ Kunreuther and Heal (2003).

${ }^{58}$ It is worth noting that, in the case of terrorism, this would be mainly due to difference in perceived risk rather than to any asymmetry of information between an insured and the insurance company regarding the risk the insured faces (traditional adverse selection). As a matter of fact, due to the difficulty to quantify the risk of terrorism, the main problem would rather be symmetry of non-information between the insured and insurers on the current level of exposure.
} 
On the other hand, it still seems difficult - other than theoretically - to compare the current system with how the French market would look should commercial coverage not be compulsory. As discussed, terrorism insurance premiums are based only on insured value and not on firms' exposure. This limits the interest for modelling firms in developing some activities in France. ${ }^{59}$ In fact, the national scale of premiums remains unchanged 3 years after GAREAT's establishment. Without advanced estimation of terrorism risk and potential damages associated with a wide range of scenarios of attack on French soil, and then a forecast of what the demand would be, based on the knowledge of that exposure, this economic comparison - mandatory/non-mandatory - remains impossible.

\section{The German market}

In Germany, the demand for terrorism insurance has been very low. As of August 2004, according to data provided by Extremus, the number of contracts managed by the company amounts to 1,013 with a total annual premium income of $€ 77$ million, sums insured of $€ 365$ billion and maximum annual compensation of $€ 74$ billion. As there exist an estimated 40,000 firms exposed to risk over the $€ 25$ million threshold in Germany, this leads to an estimate of only 2.5 per cent of contracts covered for terrorism. ${ }^{60}$

According to a survey published in 2003, only 13 of the 30 DAX companies ${ }^{61}$ had insurance contracts with Extremus. ${ }^{62}$ Moreover, a closer look at the market shows that while the number of contracts remains similar, the absolute demand for coverage has declined even since the reporting period 2003, when the total net premium income amounted to $€ 103$ million with sums insured of $€ 653$ billion and maximum annual compensations of $€ 81$ billion. From these numbers, it can be concluded that this decrease is due to the loss of some contracts with sums insured considerably higher than $€ 1.5$ billion. This decline is all the more surprising after the terror alerts for the German army hospital in Hamburg at the end of December 2003 and the terrorist attacks in Madrid on March 11, 2004. ${ }^{63}$

\section{The U.S. market}

The passage of TRIA at the end of 2002 made insurance available nationwide, but there were initially few takers. ${ }^{64}$ The U.S. Council of Insurance Agents and Brokers

\footnotetext{
${ }^{59}$ Modelling firms such as AIR, RMS or EQECat developed new models to quantify terrorism risk considering thousands of possible scenarios and targets; to date, they mainly operate in the U.S. for that purpose (Kunreuther et al., in press).

${ }^{60}$ This estimate has to be dealt with carefully as the size of the contracts is not accounted for, but according to the expert opinion of members of Extremus, it gives a fairly realistic picture and underlines the prevailing very low dimension of market penetration. Unfortunately, it is impossible to get more precise information for the time being.

${ }^{61}$ The DAX (or DAX30) comprises the 30 largest listed companies in terms of market capitalization of the free float.

${ }^{62}$ Frankfurter Allgemeine Zeitung (2003).

${ }^{63}$ Extremus (2004).

${ }^{64}$ Treaster (2003).
} 


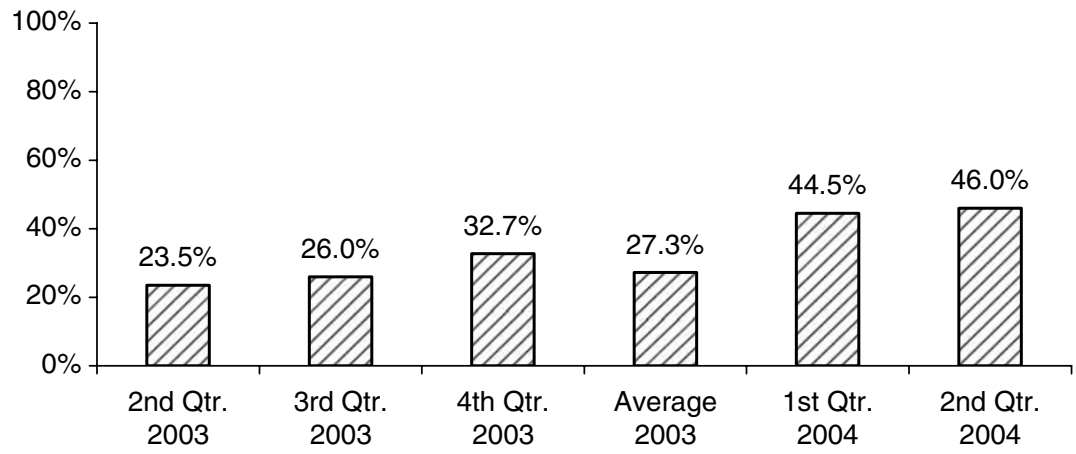

Figure 5. Terrorism take-up rates by quarter (U.S. market).

$(\mathrm{CIAB})^{65}$ undertook the first study on the level of demand for terrorism coverage. According to this study, 72 per cent of the brokers indicated that their commercial customers were still not purchasing terrorism insurance coverage at the beginning of 2003. ${ }^{66}$ Even in locations like New York City, the level of demand remained low. In the autumn of 2003, the New York-based insurance brokerage firm Kaye Insurance Associates surveyed 100 of its clients in the New York area on a series of insurancerelated issues, including terrorism insurance. According to this survey, only 36 per cent of the companies surveyed had bought terrorism insurance. ${ }^{67}$ This level of demand was confirmed at a national level over the last three quarters of 2003 through 2,400 firms surveyed by Marsh, as depicted by Figure $5 .{ }^{68}$

More recent data show that the take-up rates have been increasing throughout 2004. In particular, data compiled over 800 businesses and government entities, which renewed property insurance policies in the second quarter of 2004, indicated that 46 per cent of them had bought terrorism insurance, compared to nearly 33 per cent in the fourth quarter of $2003 .^{69}$ Since the overall pricing for commercial property insurance has continued to decrease, it is likely that firms have freed up funds to purchase terrorism coverage. Moreover, recent alerts released by the U.S. federal government of possible attacks to the country certainly have increased firms' concerns.

In any case, even if the demand for terrorism coverage in the U.S. has increased over the past year, the majority of firms operating there still have not purchased terrorism insurance. This may mean that a 9/11-size attack would very likely have much more impact on firms' liquidity and business continuity today than after September 11, when all firms were covered against terrorism and losses were diversified on worldwide insurance and reinsurance markets.

\footnotetext{
${ }^{65}$ The council represents the top tier of the nation's insurance brokers who collectively write 80 per cent of the commercial property/casualty premiums annually.

${ }^{66}$ CIAB (July 2003).

${ }^{67}$ Kaye Insurance Associates (2003).

${ }^{68}$ Marsh Inc. (August 2004).

${ }^{69}$ Ibid.
} 


\section{Perspectives on the level of demand}

Several elements can contribute to explaining such a low degree of market penetration. First, this may be due to the specific design of the scheme itself. Let us consider the German market, for which the level of demand is currently the lowest. The operation of Extremus raises some fundamental questions in this regard. Regarding eligibility for coverage, there is limitation to risks located in Germany, which excludes foreign affiliates affected by a terrorist attack in Germany. Because of the financial involvement of the government, it is very unlikely that an agreement extending the coverage to foreign affiliates will be reached. In addition, all sites of a firm have to be included. This means it is not possible to get coverage only for specific sites or production facilities; it is an all or nothing coverage. It is obvious that these limitations do not make coverage against terrorism risk by Extremus particularly attractive for large international conglomerates. Regarding the premiums, the German scheme differentiates premiums only with respect to sum insured and maximum annual compensation. Characteristics of individual companies and sites are not taken into account. Finally, on the scope of coverage, insurance is limited to property and business interruption. Nuclear risks as well as biological and chemical contamination by terrorists are not covered.

As a reaction to the low level of demand, Extremus is currently considering two major modifications in its operations. On the one hand, it plans to give the insureds upward and downward options for their deductible, which is currently fixed at 1 per cent of the maximum annual compensation. While it may be interesting for industrial clients to choose higher deductibles in order to lower their premiums, real estate funds are pushing for deductibles as low as 1 per thousand because of their liability for statements made in prospectus. The second modification would relate to business interruption interdependency losses. This coverage would also insure against business interruption losses suffered by a German insured that were caused by a terrorist attack in another European Union country, interrupting the supply chain from an affiliated company in that country. Consider, for example, a German corporate group with its head office and final assembly in Munich that also has an affiliated company located in Paris that supplies components. If a terrorist attack against the French supplier occurs, the direct losses suffered by the affiliate would be covered by its terrorism insurance contract issued in France and the business interruption losses, suffered by the final assembly in Munich due to the interruption of the supply chain, would be covered by Extremus. A sub-limit of the sum insured with Extremus would apply to this coverage. This modification is still subject to governmental approval but it would be interesting to see how this affects the demand for terrorism coverage among international firms. In any case, this constitutes an interesting move toward terrorism insurance coverage that better deals with the increasingly interdependent nature of business.

Secondly, the way people make decisions when facing uncertainty plays an important role on their decision to purchase terrorism insurance. As documented by research on insurance against other catastrophic risks such as natural disasters, this may result from an "it cannot happen to me" effect so that insurance is not considered 
necessary. ${ }^{70}$ Three years after $9 / 11$, the concern for damage from terrorism has assumed a back seat in most people's minds. Today, most firms believe that if a terrorist attack occurs, it will not happen to them, whereas just after 9/11 they held the opposite view. For example, the aforementioned 2003 U.S. CIAB study indicated that more than 90 per cent of the brokers said that their customers eschew terrorism insurance because they think they do not need it. ${ }^{71}$ The Kay survey also asked those who had not yet purchased terrorism coverage why they had not done so, and the top reason was that the company was not seen as a target (66 per cent), followed by high cost $(17$ per cent $) .^{72}$

Thirdly, the government cannot credibly commit ex ante to not bailing out the noninsured post attacks. Some firms might believe that the government will bail them out in case of another attack, thus limiting the interest in purchasing insurance coverage which - considering for example the large range of possible scenarios of CBRN attacks - would be at best partial coverage. Indeed, while the overall so-called Samaritan's dilemma effect is not clear $a$ priori ${ }^{73}$ it is likely to influence some firms not purchasing terrorism insurance.

Finally, for a certain type of firms the choice not to purchase terrorism insurance can be considered rational when viewed from a corporate risk management perspective. ${ }^{74}$ After all, most large firms are owned by diversified shareholders among whom a loss due to a terrorist attack would be shared. Eventually, insurance is only one tool a firm can use to diversify its risks and it may not be always the most financially attractive one.

As a whole, it is likely that each of these elements plays out differently for firms in different industries and countries regarding their choice to purchase terrorism insurance or not. Additional research is needed to better understand how each element affects that decision and whether one of them has more explanatory power depending on firms' characteristics such as size, assets, capital allocation and industry.

\section{Conclusion}

This paper has discussed the operation of terrorism insurance programmes established in France, Germany and the U.S as a reaction to $9 / 11$. These three programmes are all based upon a public-private partnership. They are also similar in that (1) governmental participation has been, at least initially, limited to a few years; (2) there is a minimum sum insured (and respectively, a minimum of insured losses in the U.S.); (3) the programme does not cover firms outside national borders; (4) the exposure of the private sector is limited, with the government acting as a reinsurer of last resort.

\footnotetext{
${ }^{70}$ Kunreuther (1996).

71 CIAB (2003).

72 Kaye (2003).

73 Buchanan (1975).

${ }^{74}$ Doherty (2000).
} 
However, there are some fundamental differences between the three programmes, as summarized in the Appendix. They differ with respect to price differentiation: while there is a national rating scale in France and Germany, the U.S. TRIA leaves it up to insurers to set rates under state regulations. Accordingly, there is price differentiation with respect to risk location in the U.S., which is not the case in France where prices are based on the total sum insured of each firm and in Germany where prices are based on the total sum insured and the maximum annual compensation for terrorism coverage no matter what the location. Recent data on prices for terrorism insurance in these three countries are provided in this paper. Three years after $9 / 11$, and without any new attack on U.S. soil, terrorism insurance premiums there have been decreasing. Moreover, the U.S. programme is the only one that provides governmental reinsurance free of charge.

This paper also provides some evidence on the demand for terrorism insurance in France, Germany and the U.S. Terrorism coverage is mandatory for all firms only in France, with the obligation for every insurer and mutual company to be reinsured by the pool GAREAT, possibly crowding out pure private solutions. On the other hand, the low dimension of market penetration in the U.S. and especially in Germany shows that the attractiveness of these two schemes has to be improved to induce a higher degree of underwriting of terrorism coverage; some compulsory elements might be required to achieve that goal. If coverage remains at the current level in the future, another large-scale attack would certainly have a much greater impact on the social and economic continuity of these two countries. Indeed, the largest part of losses would be supported directly by the victims and not by national and international insurance and reinsurance companies. Whether terrorism coverage should be required by private institutions (e.g. by banks as a condition of mortgage) or even by the government remains an open question.

Recent changes in the nature of international terrorism worldwide indicate, alas, that these issues will remain in our future. ${ }^{75}$ They also provide evidence that no country can be viewed today as immune to international terrorism as the world is becoming more and more global, increasing interdependencies across borders. Moreover, it is likely that terrorism will take on various forms in the future that would go beyond our current interpretation of terrorists' rationality.

In that context, the question of who should pay for terrorism risk prevention and sustainable coverage within a country is likely to be seen first as a matter of collective responsibility that each country has to consider - a societal choice. National components, such as characteristics of the insurance market and the national homeland security policy, as well as habits, cultures and references, play a prime role in the implementation and improvement of any national programme. On the other hand, decision makers in both the private and the public sectors now face global threats that go far beyond national frontiers. Hence, we think that government and industry would at the very least benefit from a better understanding of how others operate abroad.

\footnotetext{
${ }^{75}$ Kunreuther and Michel-Kerjan (forthcoming); National Commission (2004).
} 


\section{References}

Aon Re Worldwide (2003) 'Terrorism insurance and reinsurance solutions: a revolution in Europe'. Available at www.aon.com.

Brown, J.R., Cummins, J.D., Lewis, C. and Wei, R. (2004) An Empirical Analysis of the Economic Impact of Federal Terrorism Reinsurance, presented at NBER Insurance Group Workshop, February, Cambridge, MA.

Brown, J., Kroszner, R. and Jenn, B. (2002) Federal terrorism insurance, NBER working paper 9271, Cambridge, MA, October 2002.

Buchanan, J. (1975) 'The samaritan's dilemma', in E. Phelps (ed.) Altruism, Morality and Economic Theory, New York: Russell Sage Foundation.

Council of Insurance Agents and Brokers (2003) Commercial Market Index Survey, News Release, July 22.

Cummins, J.D. and Doherty, N. (2002) Federal Terrorism Reinsurance: An Analysis of Issues and Program Design Alternatives, paper presented at the NBER Insurance Project Workshop, Cambridge, MA, Feb. 1.

De Mey, J. (2003) 'The aftermath of September 11: The impact on and systemic risk to the insurance industry', Geneva Papers and Risk and Insurance - Issues and Practices 28(1): 65-70.

Dubois, J. (2004) Oversight of the Terrorism Risk Insurance Program, Testimony of the Chairman and CEO of Swiss Re America Holding on behalf of Swiss Re before the U.S. Senate Committee on Banking, Housing and Urban Affairs, May 18.

Doherty, N. (2000) Integrated Risk Management: Techniques and Strategies for Reducing Risks, New York: McGraw-Hill.

Extremus Versicherungs-AG (2004) Press Release March 24, 2004.

Extremus Versicherungs-AG (2003) Kurzdarstellung der Gesellschaft und Deckung, Cologne.

Frankfurter Allgemeine Zeitung (2004) March 25, 2004, p. 19.

Frankfurter Allgemeine Zeitung (2003) April 1st 2003, p. 16.

GAREAT (2004) The French Terrorism Reinsurance Pool, Internal Communication Presentation.

Gas, B. and Thomann, C. (2003) 'Wer trägt das Terrorrisiko? Zeitschrift für die gesamte Versicherungswissenschaft 92: 697-723.

Godard, O., Henry, C., Lagadec, P. and Michel-Kerjan, E. (2002) Treatise on New Risks, Precaution, Crisis Management and Insurance, Paris: Editions Gallimard, Folio-Actuel, Inedit 100, p. 620.

Gron, A. and Sykes, A. (2002) 'Terrorism and insurance markets: a role for the government as insurer?', Regulation Winter 2002-2003: 44-51.

Hale, D. (2002) 'America uncovered', Financial Times September 12.

Hartwig, R. (2004) The fate of TRIA: Is terrorism an insurance risk?, Insurance Information Institute, New York, NY.

Hsu, S. (2003) D.C. Disputes Insurance Study Raising Rates for Terrorism, Washington Post January 7, page A01.

Hubbard, G. and Deal, B. (2004) 'The economic effects of federal participation in terrorism risk', Analysis Group September 14.

Jaffee, D. and Russel, T. (2003) 'Markets under stress: The case of extreme event insurance', in Arnott, Greenwald, Kanbur and Nalebuff (eds) Economics for an Imperfect World: Essays in Honor of Joseph Stiglitz, Cambridge, MA: MIT Press.

Kaye Insurance Associates (2003) Middle Market Survey, October 2003, New York.

Kunreuther, H. and Michel-Kerjan, E. (in press) 'PolicyWatch: Challenges for Terrorism Risk Insurance in the United States', Journal of Economic Perspectives.

Kunreuther, H. and Michel-Kerjan, E. (forthcoming) Insurability of (Mega)-Terrorism. Challenges and Perspectives Report for the OECD Task Force on Terrorism Insurance, Organization for Economic Cooperation and Development, Paris.

Kunreuther, H., Michel-Kerjan, E. and Porter, B. (in press) 'Extending catastrophe modeling to terrorism and other extreme events', in P. Grossi and H. Kunreuther (eds) with C. Patel, Catastrophe Modeling: A New Approach to Managing Risk, Boston: Kluwer Academic Publisher.

Kunreuther, H. and Heal, G. (2003) 'Interdependent security', Journal of Risk and Uncertainty 26(2/3): 231-249.

Kunreuther, H., Michel-Kerjan, E. and Porter, B. (2003) 'Assessing, Managing and Financing Extreme Events: Dealing with Terrorism' US National Bureau of Economic Research, Working paper 10179, December NBER, Cambridge, MA. 
Kunreuther, H. (1996) 'Mitigating disaster losses through insurance', Journal of Risk and Uncertainty 12: 171-187.

Lane, M. (ed) (2002) Alternative Risk Strategies, London: Risk Books, Haymarket House, May 2002.

Lelain, P., Bonturi, M. and Koen, V. (2002) The economic consequences of terrorism OECD Working paper 334 Department of Economics, OECD: Paris.

Liedtke, P. and Courbage, C. (eds) (2002) Insurance and September 11 One Year After. Impact, Lessons and Unsolved Issues, Geneva: The International Association for the Study of Insurance Economics.

MacDonald, J. (2004) 'Terrorism, insurance, and TRIA: Are we asking the right questions? The John Liner Review 18(2): 87-96.

Marsh Inc. (2004) Marketwatch: Property Terrorism Insurance. Update-2nd Quarter 2004 August 2004.

Marsh Inc. (2004) Marketwatch: Property Terrorism Insurance, April 2004.

Michel-Kerjan, E. (2003a) 'Aux Etats-Unis, la menace terroriste reste dans tous les esprits', Interview for the French Newspaper Le Monde June 11.

Michel-Kerjan, E. (2003b) 'Large-scale terrorism: Risk sharing and public policy', Revue d'Economie Politique 113(5): 625-648.

Morgan, S. (2004) Assessing Insurer's Terrorism Risk, Equity Research, Insurance - Property and Casualty, March 19.

National Commission on Terrorist Attacks Upon the United States (2004) The 9/11 Commission Report, Washington, DC, July.

Nell, M. and Richter, A. (2004) 'Improving Risk Allocation through indexed cat bonds', The Geneva Papers on Risk and Insurance - Issues and Practices 29(2): 183-201.

Partner Re (2004) Terrorism Insurance Available onwww.partnerre.com May 2004.

Pillar, P. (2001) Terrorism and U.S. Foreign Policy, Washington, DC: Brookings Institution Press.

Richter, A. (2004) 'Moderne Finanzinstrumente im Rahmen des Katastrophen-Risk-Managements: Basisrisiko versus Ausfallrisiko', Zeitschrift für betriebswirtschaftliche Forschung 56(2): 99-121.

Russell, T. (2003) The Costs and Benefits of the Terrorism Risk Insurance Act: A First Look, paper presented at the NBER Insurance Group workshop, January 30, NBER, Cambridge, MA.

Sandler, T. and Enders, W. (2004) 'An economic perspective of transnational terrorism', European Journal of Political Economy. 20(2): 301-316.

Smetters, K. (2004) Insuring against Terrorism: The Policy Challenge, paper presented at the joint BrookingsWharton Conference on Financial Services, January 8-9, Brookings Institution, Washington, DC.

Swiss Re (2004) Insurance-Linked Securities Quarterly, New York: Swiss Re Capital Markets Corporation, January.

Towers, P. (2004) Workers' Compensation Terrorism Reinsurance Pool Feasibility Study March.

Treaster, J. (2003) 'Insurance for terrorism still a rarity', New York Times March 8.

U.S. General Accounting Office (GAO) (2003) Catastrophe Insurance Risks. Status of Efforts to Securitize Natural Catastrophe and Terrorism Risk, GAO-03-1033, Washington, DC, September 24.

U.S. General Accounting Office (GAO) (2002) Terrorism Insurance: Rising Uninsured Exposure to Attacks Heightens Potential Economic Vulnerabilities Testimony of Richard J. Hillman Before the Subcommittee on Oversight and Investigations, Committee on Financial Services, House of Representatives, February 27.

U.S. General Accounting Office (GAO) (2001) Terrorism Insurance: Alternative Programs for Protecting Insurance Consumers, Testimony of Thomas McCool Before the Committee on Banking, Housing and Urban Affairs, U.S. Senate, October 24.

White House (2002) National Strategy for Homeland Security, Washington, DC, July 2002.

Woo, G. (2004) A Catastrophe Bond Niche: Multiple Event Risk, Paper presented at the NBER Insurance Group Workshop, Cambridge, MA, February 7.

\section{About the authors}

Erwann Michel-Karjan is Research Fellow at the Wharton School's Center for Risk Management and Decision Processes, a centre with nearly 20 years of experience in understanding decision processes and developing strategies for dealing with low 
probability-high consequence events that he joined in 2002. Dr. Michael Kerjan's work is on strategic crisis management and on managing and financing extreme events. In particular, his interest is in the creation, implementation and development of private-public partnerships to deal with large-scale emerging risks. A member of the American Risk and Insurance Association and associate researcher at the Ecole Polytechnique in Paris, he serves as an expert for the OECD Task Force on Terrorism Insurance.

Burkhard Pedell is Assistant Professor at the Institute of Production Management and Management Accounting of the Munich School of Management, University of Munich. He was a Postdoctoral Fellow at the Wharton School's Center for Risk Management and Decision Processes in 2002. Dr. Pedell's major research interests include rate regulation, public-private partnerships, value-based management, risk management and performance measurement. In particular, the focus of his work is on regulatory risk and cost of capital for rate-regulated firms.

\section{Appendix}

Comparison of the three public-private partnerships

\begin{tabular}{|c|c|c|c|}
\hline & GAREAT (France) & Extremus (Germany) & TRIA (U.S.) \\
\hline $\begin{array}{l}\text { Basic structure of the } \\
\text { partnership for an- } \\
\text { nual aggregate losses }\end{array}$ & $\begin{array}{l}\text { Co-reinsurance pool } \\
\text { with unlimited state } \\
\text { guarantee for losses } \\
\text { higher than } € 2.00 \\
\text { billion }\end{array}$ & $\begin{array}{l}\text { Insurance company } \\
\text { with federal reinsur- } \\
\text { ance of last resort for } \\
\text { losses higher than } € 2 \\
\text { (3) billion and less } \\
\text { than } € 10 \text { (13) billion } \\
\text { in } 2004 \text { (in 2002, } \\
2003 \text {, respectively) }\end{array}$ & $\begin{array}{l}\text { Risk-sharing arrange- } \\
\text { ment between the fed- } \\
\text { eral government and } \\
\text { insurers, up to } \$ 100 \\
\text { billion }\end{array}$ \\
\hline $\begin{array}{l}\text { Limited exposure of } \\
\text { the private sector }\end{array}$ & $\begin{array}{l}€ 1.5 \text { billion (2002) } \\
€ 1.75 \text { billion (2003) } \\
€ 2 \text { billion (2004) }\end{array}$ & $\begin{array}{l}€ 3 \text { billion in } 2003 \\
€ 2 \text { billion in } 2004\end{array}$ & $\begin{array}{l}\text { Market retention as } \\
\text { defined by TRIA } \\
\$ 10 \text { billion }(2003) \\
\$ 12.5 \text { billion }(2004) \\
\$ 15 \text { billion }(2005)\end{array}$ \\
\hline $\begin{array}{l}\text { Estimations of the } \\
\text { total } 2004 \text { terrorism } \\
\text { premiums }\end{array}$ & $€ 260$ million & $€ 77$ million & $\begin{array}{l}\text { \$3.6 billion } \\
\text { (See U.S. TRIA } \\
\text { section) }\end{array}$ \\
\hline
\end{tabular}

\begin{tabular}{llll}
\hline $\begin{array}{l}\text { Temporary govern- } \\
\text { mental involvement }\end{array}$ & $\begin{array}{l}\text { Yes. Agreement with } \\
\text { the government lim- }\end{array}$ & $\begin{array}{l}\text { Yes. Agreement with } \\
\text { the federal govern- }\end{array}$ & $\begin{array}{l}\text { Yes. Agreement with } \\
\text { the federal govern- } \\
\text { ited to the end of } \\
\text { 2003; renewed to the } \\
\text { end of } 2006 .\end{array}$
\end{tabular}


Erwann Michel-Kerjan and Burkhard Pedell Terrorism Risk Coverage in the Post-9/11 Era

Gratuity of govern-
mental coverage

No. Government receives premiums for its unlimited guarantee
No. Government receives premiums

for its guarantee
Yes

\begin{tabular}{lll}
\hline $\begin{array}{l}\text { Compulsory } \\
\text { insurance }\end{array}$ & Yes & No
\end{tabular}

No

\begin{tabular}{llll}
\hline $\begin{array}{l}\text { Minimum sum } \\
\text { insured }\end{array}$ & $€ 6$ million & $\begin{array}{l}€ 25 \text { million } \\
\text { (refers to the basic } \\
\text { sum insured in the } \\
\text { conventional insur- }\end{array}$ & $\begin{array}{l}\text { No minimum sum in- } \\
\text { sured, but a minimum } \\
\text { ofce policy; smaller } \\
\text { losses to be covered } \\
\text { by TRIA }\end{array}$ \\
$\begin{array}{l}\text { limit for terrorism } \\
\text { coverage might be } \\
\text { chosen by insured) }\end{array}$ & $\begin{array}{l}\text { Yes } \\
\begin{array}{l}\text { Risk pricing: } \\
\text { predefined rate scale }\end{array}\end{array}$ \\
$\begin{array}{l}\text { Insurance price } \\
\text { depends on risk } \\
\text { location }\end{array}$ & Yes & No & No \\
\hline $\begin{array}{l}\text { Risk segmentation by } \\
\text { sum insured }\end{array}$ & Yes & Yes & Yes \\
\hline
\end{tabular}

\section{The Spanish Programme, Consorcio de Compensación de Seguros}

The Consorcio de Compensación de Seguros obtained permanent legal status in 1954 and hence constitutes the oldest terrorism insurance programme in Europe. It is a state insurance programme guaranteeing coverage for "extraordinary risks", and is mandatory in Spain for both natural disasters (e.g. earthquake, flood, atypical cyclone storm, volcanic eruption) and phenomena with political-social effects (civil commotion, rebellion, and terrorism). Terrorism risk is thus not covered separately. The coverage is for property damage only and is integrated into policies issued by private insurance companies that collect premiums on behalf of Consorcio.

As in France and Germany, the reinsurance rates charged by the Consorcio depend on the sum insured. For example, for full compulsory coverage (material damage), the Consorcio charges between $0.10 \%$ and 0.14 per thousand for office buildings, and between 0.21 per thousand and 0.25 per thousand of sum insured for industrial premises. Following 9/11, the Consorcio agreed to reinsure terrorism risk with respect to business interruption for all risks located in Spain; it charges an annual rate of 0.15 per thousand on the sum insured for business interruption reinsurance coverage. ${ }^{a}$ Again, these rates are for coverage against the complete range of "extraordinary risks" and not only for terrorism. In the aftermath of the March 11, 2004 terrorist attacks in Madrid, Spain's terrorism insurance pool covered the majority of the associated loss, other than life insurance and damage to trains that are state-owned. 
170

\section{The U.K. Programme, Pool Re}

In the wake of the terrorist bomb explosions in the City of London in April 1992 and an announcement 7 months later by British insurers that they would exclude terrorism coverage from their commercial policies, the U.K. established a mutual insurance organization (Pool Re) to accommodate claims following terrorist activities. The U.K. treasury as the reinsurer of last resort backs Pool Re. Until September 11, 2001 terrorism exclusions within insurance policies in the UK were usually limited to property policies. They were based on the Terrorism Act of 1993 and designed to deal with the IRA bombing campaign on mainland Britain.

The scale of $9 / 11$ attacks in the U.S. led to the need for extending protection under Pool Re to "all risks" (including damage caused by chemical and biological as well as nuclear contamination), taking effect on January 1,2003 . This extension in coverage to all risks was reflected by a doubling of the pre September 11 , 2001 premiums charged by the pool. Pool Re charges its nearly 220 members a separate, optional premium for terrorism coverage that can be calculated as a percentage of the total sum insured under a fire and accident policy. This premium depends on location of the risk, with the highest rate at 0.6 per thousand of the sum insured in Central London. Business interruption is charged at 0.21 per thousand in all risk zones. ${ }^{b}$ Moreover, insurers are now free to set the premiums for underlying terrorism policies, thereby introducing competition into the terrorism insurance market. A maximum insurance retention is set up, with individual insurers' retentions being based on market share. It was set at $£ 30$ million ( $€ 43$ million) per event and $£ 60$ million ( $€ 86$ million) per annum for 2003 ; and it will increase up to $£ 100$ million ( $€ 144$ million) per event and $£ 200$ million ( $€ 288$ million) per annum for 2006 .

\footnotetext{
${ }^{\mathrm{a}}$ Aon Re (2003).

${ }^{\mathrm{b}}$ Ibid.
} 